longitudinal trim. Radar observations will also be made on the flight path. All this involves a new research technique, and early experiments will be mainly concerned with perfecting it. Step by step it is hoped to reach the position where enough information will be available to design a supersonic radio-controlled aircraft. The rocket thrust is about $850 \mathrm{lb}$. acting for some 70 sec. An auto-pilot controls the model in pitch and roll. It is proposed to release the model at $36,000 \mathrm{ft}$. from a Mosquito aircraft, when the controls will operate to cause it to glide down to $35,000 \mathrm{ft}$. The rocket motor will then be switched on to accelerate the model in roughly level flight, at this height, to an estimated Mach number of about $1 \cdot 3$. When the fuel is all burnt the model will decelerate, its speed passing through that of sound to subsonic velocity; so a double chance will occur of getting readings in the critical transonic region before the automatic controls operate to crash the model into the sea. The models have been designed by Mr. B. N. Wallis, of Vickers-Armstrong, and made there in collaboration with the Royal Aircraft Establishment, which is responsible for the conduct of these experiments. The experiments should start in about a month's time off the Scilly Isles.

\section{Chemistry at the University of Sheffield}

The Staveley Coal and Iron Co., Ltd., near Chesterfield, has decided to make a gift of $£ 50,000$ to the University of Sheffield in order to promote the furtherance of research within the University and especially in the Department of Chemistry. The Company, which is concerned with the production of iron, caustic soda, chlorine, hydrochloric acid, chlorates, aniline and a wide range of basic coal-tar products, takes the view that encouragement of free chemical research in universities must, in the long run, benefit both the Company and industry as a whole, and believes that the connecting of industrial development with academic discovery is essential for national prosperity. Its gift to Sheffield is most opportune, as the provision of a new Department of Chemistry is one of the most urgent parts of the post-war plans of the University's extension scheme. It is intended to replace the existing laboratories, built in 1905 , by an entirely new department which will be close to the present building of the University in Western Bank. The new building has been designed to provide adequate space for all the work in the Department when the University attains its projected number of 3,000 full-time students in all faculties, and adequate research facilities will be provided for investigations in analytical, inorganic, physical and organic chemistry. It is estimated that the cost of the erection of the new Department will exceed $£ 400,000$, and it is proposed that the research laboratories therein should be named the "Staveley Laboratories".

\section{A New Rat Poison}

To the well-known list of rat poisons, such as arsenic trioxide, red squill and zinc phosphide, the last years of the War added another, $\alpha$-naphthathiourea. Dr. C. P. Richter, of Baltimore, was responsible for showing that its toxicity to Rattus norvegicus was high (A.L.D./50, $10 \mathrm{mgm}$. per kilo body-weight). Somewhat extravagant claims were made for its effectiveness when applied as a direct bait. In none of the field tests were accurate censuses made of the rat population before treatment. Prolonged and detailed experience in Great Britain at the Bureau of Animal Population has shown that knowledge obtained by bait census is essential before field trials are undertaken. The use of $\alpha$-naphtha. thiourea as a dusting powder, however, opened up possibilities of a new method of application, but its usefulness depended upon the safety factor involved. Toxicity tests made on other animals showed an enormous range of sensitivity. $R$. rattus, the ship or black rat, had an A.L.D. $/ 50$ of $250+$ mgm. per kilo body-weight, more than twenty-five times that for $R$. norvegicus, while Mus musculus, the house mouse, had an A.L.D./50 of 80-90 mgm. per kilo body-weight. These data showed that it was impossible to predict a safety-level from one species to another. Consequently, although tests on monkeys (Macacus sp.) showed a high resistance, it was dangerous to assume that man was equally immune. Dusting application was therefore not advised in Great Britain until more information was available.

Used in baits, following the pre-baiting technique worked out by the Bureau of Animal Population, $\alpha$-naphthathiourea gave results as good as those with arsenic and zinc phosphide, namely, 90 per cent kills ; used as a direct bait without prebaiting, some successes were met with, but also the usual failures (for example, 40 per cent kill). Since the failure to exterminate rats is largely due to the hit and miss nature of direct baiting which has been employed for so long, there seemed no grounds for regarding $\alpha$-naphthathiourea as any considerable advance on the well-established poisons. $\alpha$-Naphthathiourea is now being marketed by the Rodmill Chemical Co., Ltd., as 'Antu', containing 2 per cent of the active principle. As a ready-to-use compound bait, 'Antu' must be classed with the direct baits which do not allow the purchasing public to pre-bait and ensure success. It is also being recommended as a dusting powder for use in rat runs, on beams and elsewhere "inaccessible to domestic animals"-places which may be hard to find. From the point of view of rodent control, it is to be regretted that $\alpha$-naphthathiourea is not being marketed at a 20 per cent concentration in an inert medium and so allowing the public to obey the recommendations of the Infestation Division of the Ministry of Food to pre-bait before poisoning, a technique worked out by the Bureau of Animal Population during the War, which has proved itself again and again to be the only really certain way of exterminating rats.

\section{Exhibition of Applied Photography}

AN Exhibition of Applied Photography arranged by Kodak Ltd. at Australia House, Strand, London, was opened on May 6 by Prof. E. N. da C. Andrade. The exhibits illustrate a very wide range of industrial and commercial applications of photography, the applications being illustrated by photographs, diagrams and in some cases demonstrations. Photography received a fair amount of publicity during the War, particularly on account of its obvious importance for air reconnaissance. There were, however, many other applications less spectacular, but nevertheless of great value, many of which are illustrated in some form in this exhibition. Most of these applications have come to stay and will play a useful part in peace-time industry. The range covered by the exhibition is very wide; on the spectacular side is a full-sized radiograph of a 'Jeep' to set against the purely utilitarian micro-copying of documents. Other exhibits include industrial radiography, gamma radiography, stereoscopy, photography in education, colour reproduction and the reproduction of drawings 
on metal. Among the most interesting exhibits are the 16-mm. projectors showing continuously running films of mechanical and manual operations, some in slow motion, to illustrate how an analysis of the motion can be used to speed up, or reduce fatigue in, the operation. Most of the exhibits illustrate industrial applications of photography, and the whole provides an interesting collection well worth a visit. The exhibition remains open until May 16.

\section{Congresses}

\section{Radiation Chemistry and Photochemistry}

A SYMPosIUM on radiation chemistry and photochemistry is being arranged at the University of Notre Dame during June 24-27. Particulars can be obtained from Prof. Milton Burton, Department of Chemistry, University of Notre Dame, Notre Dame, Indiana.

\section{Spectroscopy}

THE Groupement pour l'Avancement des Méthodes Spectrographiques is organising a general meeting to be held during June 23-25 at the Laboratoire Central de l'Armement, 1 place Saint-Thomas d'Aquin. Two sessions will be devoted to emission spectroscopy and the third more particularly to colorimetric methods of analysis. Particulars can be obtained from the offices of the Group at the place of meeting. Aeronautics

AN Aeronautical Congress will be held in London during September 3-6, at which papers will be read, followed by discussions, on the technical aspects of aviation. The Congress is being arranged by the Royal Aeronautical Society in close co-operation with the Institute of the Aeronautical Sciences of America, and about half the papers will be by American authors. A tentative programme of some twenty papers has been arranged under the following sections: aerodynamics, structures, power plants, stability and control, air-worthiness and safety, highaltitude flight, telemetering, helicopters and light (personal) aircraft. A detailed programme will be available shortly from the Royal Aeronautical Society.

\section{Physical Chemistry}

As advanced course in physical chemistry for graduates in industry, colleges of technology and schools, will be held at the University of Leeds during August 25-September 5. The main topics will be the wave nature of matter in chemistry ; molecular structure and chemical reactions ; the arrangement and structure of molecules in the solid state. Particulars of the course and forms of application may be obtained from the Director of Extra-Mural Studies, The University, Leeds 2.

\section{Cytology}

THE sixth international Congress of Experimental Cytology will meet in Stockholm during July 10-17. The Congress will consist of a series of symposia on (a) chemical constituents of the cell; (b) submicroscopic structure of protoplasm (including viruses); (c) nuclear and cytoplasmic interactions; (d) cell metabolism; (e) development, growth and differentiation. General surveys will be given, followed by discussions and short papers relating to the above subjects. The organising committee is prepared to arrange accommodation. Particulars relating to the Congress can be obtained from the secretaries, Prof. T. Caspersson and H. Hydén, Karolinska Institutet, Institute for Cell Research, Stockholm.

\section{Announcements}

A meeting in memory of Paul Langevin has been arranged by the Society for Visiting Scientists, the Association of Scientific Workers and the World Federation of Scientific Workers, to be held on May 25 at 7.45 p.m. at the Beaver Hall, Garlick Hill, London, E.C.4. Sir Henry Tizard will take the chair, and the speakers will include M. Pierre Biquard, of the French Commissariat of Atomic Energy and the Paris School of Physics and Chemistry, Sir Harold Spencer Jones, Sir George Thomson and Prof. J. D. Bernal.

Dr. Lawrence L. Lachat, senior fellow at the Mellon Institute, Pittsburgh, Pa., has resigned to accept a new position with the Chemical Research and Development Department, Armour and Co., Chicago, Ill., where he will be in charge of the development of new biochemicals which largely became available as a result of war-time research between Armour and Co. and the U.S. Office of Scientific Research and Development.

RECENT publications of the Federal Security Agency, U.S. Office of Education (Washington : Gov. Printing Office), are of interest as showing the heed paid by the United States as to the state of education in South America. Three bulletins at hand deal with Costa Rica, Colombia and Peru, and all of them merit attention by students of comparative education.

A Full report of the two-day conference on "Industry and Research" arranged by the Federation of British Industries in March, 1946 (see Nature, $157,684 ; 1946)$, has now been published by Sir Isaac Pitman and Sons, Ltd. (London, 1946. 10s. $6 d$. net). It includes a preface by Sir Clive Baillieu, and, in addition to the papers presented, the addresses of the various chairmen and reports of the discussions at the sessions on scientific research and production, scientific research and industrial expansion and the application of research in industry.

WrTH the financial help of private individuals and of the Juan Bautista Sauberan Foundation of Buenos Aires, an institute for research in fundamental branches of medicine has been organised in Córdoba, Argentina (25 de Mayo 1122); it will be known as the Instituto de Investigación Médica para Promoción de la Medicina Científica. The staff includes, among others, Dr. Oscar Orias (director), Dr. Enrique Moisset de Espanés and Dr. Inés L. C. de Allende. All three formerly held travelling fellowships of the Rockefeller Foundation; Dr. Orias working at Western Reserve and Harvard Universities with Profs. Carl J. Wiggers and the late Walter B. Cannon ; Dr. Moisset de Espanés at Harvard University with Prof. Otto Krayer, and Dr. de Allende in Rochester, N.Y., and New York, with Profs. George W. Corner and Efrain Shorr. They held posts in the Institute of Physiology in the Medical School of the University of Cordoba, but resigned after the recent changes in the administration of the universities of Argentina. The new Institute is a private institution; its main activity will be research in endocrinology, pharmacology and physiology of the circulation of the blood.

ERratum. In the penultimate paragraph of "Synthesis of Methionine and Similar Amino-Acids" by J. R. Catch et al. (Nature, April 26, p. 578), for " $\alpha$-amino- $\gamma$-thio-1- $\gamma$-methyl- $n$-valeric" read " $\alpha$-amino$\gamma$-thiol- $\gamma$-methyl- $n$-valeric". 